\title{
Effect of dietary composition and cold exposure on non-shivering thermogenesis in young pigs and its alteration by the $\beta$-blocker propranolol
}

\author{
BY M. J. DAUNCEY AND D. L. INGRAM \\ ARC Institute of Animal Physiology and MRC Dunn Calorimetry Group, Babraham, \\ Cambridge CB2 $4 A T$
}

(Received 7 August 1978 - Accepted 2 I September 1978)

1. Young pigs were fed on three diets consecutively, each diet being given for 1 week. The diets were given in random order as ( $\mathrm{g}$ pig feed $/ \mathrm{kg}$ body-weight): $(a) 20,(b) 60,(c) 20$ plus a supplement with the energy equivalent of $40 \mathrm{~g}$ pig feed $/ \mathrm{kg}$. The supplements included desiccated coconut, fish meal and glucose.

2. At the end of each week resting metabolic rate, beginning $12-14 \mathrm{~h}$ after feeding, was measured overnight using an open-circuit respiration chamber at thermoneutrality.

3. The oxygen consumption of pigs on the $60 \mathrm{~g} / \mathrm{kg}$ diet was always higher than on the $20 \mathrm{~g} / \mathrm{kg}$ diet. The addition of desiccated coconut, or fish meal also increased metabolic rate; whereas with added glucose, $\mathrm{O}_{2}$ consumption tended to be even lower than on $20 \mathrm{~g} / \mathrm{kg}$ alone.

4. The administration of the $\beta$-blocker propranolol to pigs on ad lib. food intake reduced the rate of overnight resting $\mathrm{O}_{2}$ consumption, measured from 10 until $20 \mathrm{~h}$ after feeding, by $12 \%$, but it had no effect on $\mathrm{O}_{2}$ consumption when the intake was $20 \mathrm{~g}$ feed $/ \mathrm{kg}$. Exposure to mild cold (1 $5^{\circ}$ ) caused an increase in $\mathrm{O}_{2}$ consumption and this was reduced by $14 \%$ after injection of propranolol.

Heat production in resting animals can be divided into shivering and non-shivering thermogenesis. The latter includes heat produced in association with basal metabolism, the ingestion and utilization of food and in some species exposure to cold.

The thermic effect of a meal has been known since the late eighteenth century at the time of Lavoisier and has been studied by many workers including Rubner (I902) and Lusk (I928). The production of heat after a meal is not just associated with the mechanical action of ingestion and the process of absorption, since it also occurs after the intravenous infusion of nutrients (Benedict \& Emmes, 1912; Garrow \& Hawes, 1972).

The effects of high and low levels of energy intake which have been maintained over periods of weeks have also been studied. In sheep it has been shown that the $24 \mathrm{~h}$ rate of heat production is dependent on the level of food intake only within the zone of thermal neutrality and not in a cold environment (Graham et al. 1959). More recent work with pigs confirmed this finding, again using measurements over the whole $24 \mathrm{~h}$ period (Close et al. 1971). In man the findings have been controversial. Thus Apfelbaum et al. (1971) found an increase in heat production after overfeeding, while Glick et al. (1977) did not.

In long-term studies on animals no clear distinction has been made between the effect of energy intake on the basal or resting metabolism as compared with the heat production after feeding or during activity. Nor has the relative effectiveness of presenting the extra energy intake in the form of carbohydrate, protein or fat received attention.

The mechanisms involved in the higher rate of metabolism induced by a high energy intake are poorly understood. The possibility that some basal process of metabolism is altered is supported by the finding that the rate of thyroxine utilization increases with an increase in energy intake (Evans \& Ingram, I977; Ingram \& Kaciuba-Uscilko, 1977). On the other hand the mechanism may be similar to the cold-induced thermogenesis which is controlled by the hormones of the adrenal medulla (Jansky, 1973).

The aims of the present study have been first to examine the effect of the nutrient com- 
position of a high energy intake on overnight resting metabolism, and second to determine whether the $\beta$-blocker propranolol has the same effect on the increased resting heat production associated with a high level of energy intake as it has on cold-induced thermogenesis.

\section{METHODS}

Animals. Male and female pigs of the Large White breed were used. They were aged between 6 and 8 weeks and weighed between II.9 and $\mathrm{I} 8.8 \mathrm{~kg}$ at the beginning of the study. Each animal was housed separately in a room maintained between 20 and $25^{\circ}$ and supplied with water ad lib.

Food. In the studies on the effect of dietary composition the pigs were fed for three consecutive periods of $7 \mathrm{~d}$ between 08.30 and 10.00 hours on each of three regimens presented in random order. The regimens, as $\mathrm{g}$ commercial pelleted pig feed (Kwik Meat, RHM Agriculture, Brooks Hasler Ltd, Manningtree, Essex) $/ \mathrm{kg}$ body-weight, were: 20 (just above the maintenance ration), 60 (just below an ad lib. ration, which is near to $80 \mathrm{~g} / \mathrm{kg}$ body-weight) and 20 plus the energy equivalent of $40 \mathrm{~g}$ pig feed $/ \mathrm{kg}$ body-weight given as either desiccated coconut or fish meal (Provimi 66, British White-fish Meals Ltd., Grimsby) or powdered glucose. The gross energy contents of the pig feed, desiccated coconut and fish meal were determined with an adiabatic bomb calorimeter (Gallenkamp) and that of glucose from standard tables (Hodgman, 1962). The energy and nutrient compositions are given in Table I, and the quantities of food eaten by a typical animal weighing $16 \mathrm{~kg}$ are given in Table 2. Comparisons of metabolic rates could thus be made between low and high energy intakes of the same food and between the effects of a high energy intake rich in fat, protein or glucose.

In the studies on the effect of propranolol the animals were fed at $08 \cdot 30$ hours on either $20 \mathrm{~g}$ commercial pig feed $/ \mathrm{kg}$ body-weight or ad lib. intake in the experiment on dietaryinduced thermogenesis, and on $60 \mathrm{~g} \mathrm{pig} \mathrm{feed} / \mathrm{kg}$ body-weight in the experiment on coldinduced thermogenesis. Pigs on ad lib. intake were allowed to eat until 12.00 hours and consumed approximately $80 \mathrm{~g} / \mathrm{kg}$ body-weight.

Measurement of heat production. Oxygen consumption and carbon dioxide production were determined using an open-circuit respiration chamber measuring $\mathrm{I} \cdot 2 \mathrm{~m} \times 0.6 \mathrm{~m} \times 0.6 \mathrm{~m}$. The chamber was housed inside a temperature-controlled room and provision was made for allowing the animal both to eat and to drink while inside the chamber. In determinations made overnight there was no lighting. Air entered the chamber via two inlet tubes, one of which also served to drain urine; air was then circulated in the chamber with a fan and was exhausted at a rate of $501 / \mathrm{min}$. A sample of air for analysis was withdrawn at $\mathrm{I} 1 / \mathrm{min}$, at a point near the mixing fan. The air was dried over silica gel and the concentrations of $\mathrm{O}_{2}$ and $\mathrm{CO}_{2}$ were determined using a paramagnetic analyser (Model $\mathrm{F}_{3}$; Beckman, California, USA) and an infra-red analyser (Analytical Development Co. Ltd, Hoddesdon, Herts) respectively. Both analysers were calibrated with standard gas mixtures which had been checked using a Lloyd-Haldane analyser. For $10 \mathrm{~min}$ in every hour, the analysers sampled the 'in-going' air. The output of the analysers was displayed on chart recorders and gas concentrations were determined as the difference between 'in-going' and 'out-going' samples. Results for $\mathrm{O}_{2}$ and $\mathrm{CO}_{2}$ were calculated as $\mathrm{ml} / \mathrm{kg}^{0.67}$ per min. No correction was made for differences in the volumes of 'in-going' and 'out-going' air since the respiratory quotient $\left(\mathrm{CO}_{2}\right.$ production: $\mathrm{O}_{2}$ consumption; $\left.\mathrm{RQ}\right)$ was near to unity, where the error is minimal, and the experimental differences were large in comparison with this potential error. Checks made by burning alcohol in the chamber indicated that the apparatus measured $98 \%$ of the expected $\mathrm{O}_{2}$ consumption. 
Table I. Composition $(\mathrm{g} / \mathrm{1} 00 \mathrm{~g})$ of food and supplements

$\begin{array}{lccccc} & \begin{array}{c}\text { Gross } \\ \text { energy } \\ (\mathrm{kJ} / 100 \mathrm{~g})\end{array} & \text { Protein } & \text { Fat } & \begin{array}{r}\text { Carbo- } \\ \text { hydrate }\end{array} & \begin{array}{c}\text { Dietary } \\ \text { fibre }\end{array} \\ \text { Pelleted pig feed (Kwik Meat)* } & 1580 & 18 & 2 & 62 & 5 \\ \text { Coconut, desiccated } \dagger & 2850 & 6 & 62 & 6 & 24 \\ \text { Fish meal (Provimi 66) } \ddagger & 1790 & 66 & 6 & 0 & 0 \\ \text { Glucose, powder } & 1560 & 0 & 0 & 100 & 0\end{array}$

* RHM Agriculture, Brooks Hasler Ltd, Manningtree, Essex. Constituents determined by Nutrition Chemistry Dept, MAFF, Cambridge.

+ Values from Paul \& Southgate (1978).

$\ddagger$ British White-fish Meals Ltd, Grimsby; values from manufacturers' analysis.

Table 2. Total weight $(g)$ of food and of each constituent fed per 24 to an average pig weighing $16 \mathrm{~kg}$

\begin{tabular}{|c|c|c|c|c|c|c|}
\hline \multicolumn{2}{|c|}{ Regimen } & \multirow[b]{2}{*}{ Food } & \multirow[b]{2}{*}{ Protein } & \multirow[b]{2}{*}{ Fat } & \multirow[b]{2}{*}{$\begin{array}{l}\text { Carbo- } \\
\text { hydrate }\end{array}$} & \multirow[b]{2}{*}{$\begin{array}{c}\text { Dietary } \\
\text { fibre }\end{array}$} \\
\hline $\begin{array}{c}\text { Pig feed } \\
\text { (g/kg body-wt) }\end{array}$ & Supplement & & & & & \\
\hline $\begin{array}{l}20 \\
60\end{array}$ & - & $\begin{array}{l}320 \\
960\end{array}$ & $\begin{array}{r}58 \\
174\end{array}$ & $\begin{array}{r}6 \\
18\end{array}$ & $\begin{array}{l}198 \\
594\end{array}$ & $\begin{array}{l}16 \\
48\end{array}$ \\
\hline 20 & Desiccated coconut & 507 & 69 & 122 & 209 & 61 \\
\hline 20 & Fish meal & 602 & 244 & 23 & 198 & I 6 \\
\hline 20 & Glucose & 648 & 58 & 6 & 526 & 16 \\
\hline
\end{tabular}

\section{Experimental procedure}

Effect of composition of a high energy intake on resting metabolism $12-20 h$ after feeding. During the first week after the animals had been obtained from the farm they were fed on the $20 \mathrm{~g} / \mathrm{kg}$ ration and were placed in the respiration chamber two or three times during the day and at least once overnight, in order to accustom them to the procedure. The food intake was then kept at one of the selected levels for I week before a definitive determination of overnight resting metabolic rate was made. The pigs were fed in their living quarters and transferred to the respiratory chamber at $25^{\circ}$, between 12.00 and 16.00 hours, for the determination of metabolic rate. Only those readings obtained between 22.00 and 08.00 hours were used in the analysis of the results, since during this period the chart records displayed very few variations which indicated activity or movement. When these did occur they lasted only $10-20 \mathrm{~min}$ and were omitted from the estimation of heat production.

Effect of the $\beta$-blocker, propranolol, on dietary and cold-induced thermogenesis. Animals for experiments on the effect of propranolol on dietary-induced thermogenesis were placed in the chamber at $25^{\circ}$ and propranolol (Inderal; ICI) in a dose of $5 \mathrm{mg} / \mathrm{kg}$ was injected subcutaneously at 21.00 hours. Alternatively, an injection of saline ( $9 \mathrm{~g}$ sodium chloride/1) was given as a control. Care was taken to ensure that half the animals received propranolol first and the other half saline first.

Pigs used for studying the effects of propranolol on cold-induced thermogenesis were placed in the chamber at $25^{\circ}$ and $15^{\circ}$. At $15^{\circ}$ either propranolol or saline was injected as in the study on dietary-induced thermogenesis. Determinations of overnight resting metabolism were made between 22.00 and 08.00 hours. 


\section{Analysis of results}

The hourly rates of $\mathrm{O}_{2}$ consumption for each pig on each treatment were analysed using both multivariate and individual analysis of variance. Comparisons were thus obtained between different treatments in each successive hour as well as for the over-all effect of each treatment. In addition the results were examined for any tendency for the metabolic rate to change systematically during the night.

Since sequential observations were made for each animal and for each treatment, examination of treatment differences were made using the method developed by Rowell \& Walters (1976).

\section{RESULTS}

\section{Preliminary studies on the thermic effect of a meal}

Three pigs were each kept in the respiratory chamber continuously for $5 \mathrm{~d}$ at either $15^{\circ}$ or $25^{\circ}$. They were given $60 \mathrm{~g}$ pig feed $/ \mathrm{kg}$ as one meal per $24 \mathrm{~h}$ and heat production was measured before, during and after feeding. However, the physical activity during feeding and other sporadic movements during the day made it impossible to obtain estimates of resting metabolic rate for more than a few hours during the day-time. Thus, the heat production associated only with ingestion, digestion and absorption could not be measured under these conditions. If the animal was disturbed by rattling the feeding bowl the increase in metabolism during the next $30 \mathrm{~min}$ was similar to that which occurred during feeding. In addition it was found that the RQ was approximately $\mathrm{I} \cdot \mathrm{O}$ and that propranolol had no measurable effect on the heat production during the $8 \mathrm{~h}$ after a meal.

In all later studies, estimates of heat production were made overnight when the animal was either asleep or resting. It was then possible to obtain measurements in the postabsorptive state.

\section{Effect of high energy intake of differing composition on overnight resting metabolism}

High fat intake. In the diet supplemented with desiccated coconut the pig feed was always eaten but some animals rejected up to $10 \%$ of the coconut. Fig. I gives the mean hourly rates of $\mathrm{O}_{2}$ consumption between 22.00 and 08.00 hours for the three diets for eight pigs. It shows that pigs on the $60 \mathrm{~g}$ feed $/ \mathrm{kg}$ had a higher metabolic rate than those on $20 \mathrm{~g}$ feed $/ \mathrm{kg}$ $(P<0.0 \mathrm{I})$. Feeding the additional energy as desiccated coconut resulted in a rate of $\mathrm{O}_{2}$ consumption which was between that for 60 and $20 \mathrm{~g}$ feed $/ \mathrm{kg}$ but not statistically different from either. During the night metabolic rate tended to decrease as was previously reported by Cairnie \& Pullar (1959).

High protein intake. In the eight pigs given the additional $4 \%$ energy as fish meal, there was a tendency for the animals to leave some of the fish meal. This was so marked in two instances that replacement pigs had to be used. The rejection of fish meal was never more than $15 \%$ in the animals which were used for the determination of resting metabolic rate. The results of mean $\mathrm{O}_{2}$ consumption for the eight animals are given in Fig. 2. Again the $\mathrm{O}_{2}$ consumption was higher on 60 than $20 \mathrm{~g}$ feed $/ \mathrm{kg}(P<0.01)$. Moreover the fish meal caused a statistically significant $(P<0.0 \mathrm{I})$ increase in metabolic rate above the $20 \mathrm{~g} / \mathrm{kg}$ feeding level. The metabolic rate with the fish meal diet was slightly greater than that with the $60 \mathrm{~g} \mathrm{feed} / \mathrm{kg}$, although the difference was not statistically significant.

High glucose intake. There was no rejection of glucose by the nine pigs given powdered glucose as the additional energy supplement. In marked contrast with the results for the other energy supplements, not only did the addition of glucose cause no increase in resting metabolic rate, but the rate of heat production tended to be less than that for $20 \mathrm{~g}$ feed $/ \mathrm{kg}$ 


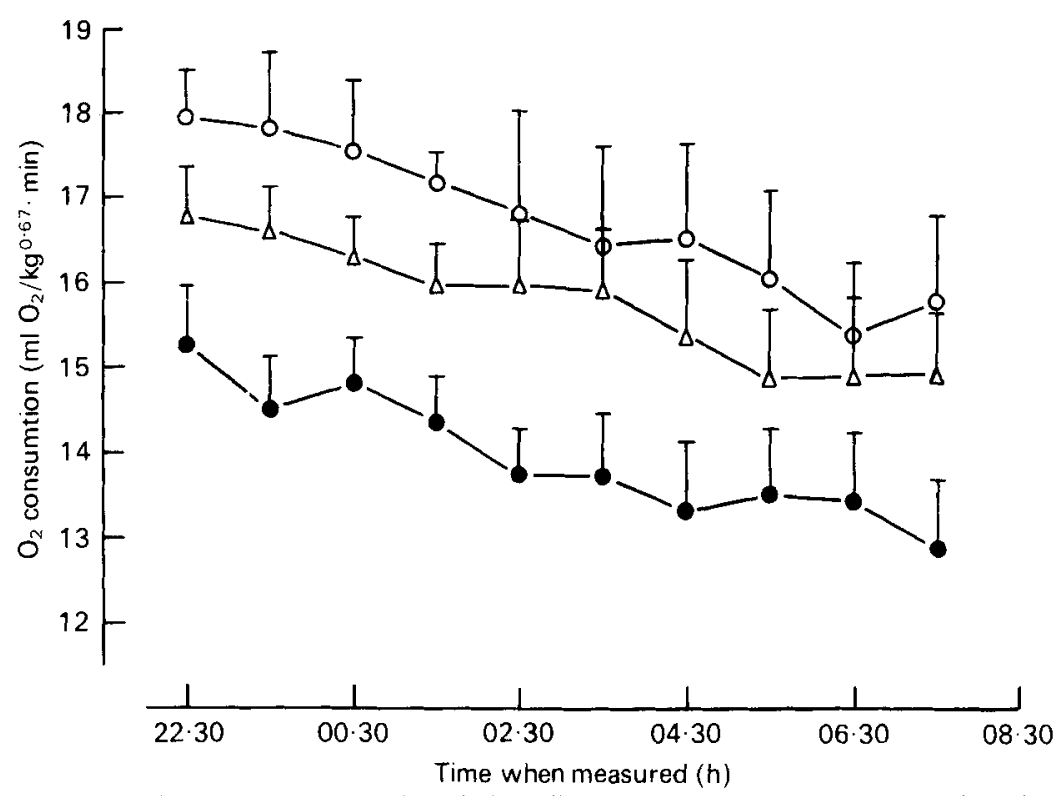

Fig. I. Rate of oxygen consumption ( $\mathrm{ml} \mathrm{O}_{2} / \mathrm{kg}^{0.62}$ per min) measured overnight in eight pigs after feeding three diets consecutively, each for $7 \mathrm{~d}$. The diets, which were fed at random, were ( $\mathrm{g}$ pig feed $/ \mathrm{kg}$ body-weight): $(O), 60 ;(0), 20 ;(\triangle), 20$ plus a quantity of desiccated coconut equivalent in energy content to $40 \mathrm{~g}$ pig feed $/ \mathrm{kg}$ body-weight. Points represent mean values with their standard errors represented by vertical bars. For details of diets, see p. 000 and Tables 1 and 2.

alone (Fig. 3). The rate of $\mathrm{O}_{2}$ consumption by pigs given $60 \mathrm{~g}$ feed $/ \mathrm{kg}$ was higher than on $20 \mathrm{~g} / \mathrm{kg}(P<0.0 \mathrm{I})$ and also higher than on $20 \mathrm{~g}$ feed $/ \mathrm{kg}$ plus glucose $(P<0.0 \mathrm{I})$.

$R Q$. The mean \pm SEM values for RQ are given in Table 3. The mean RQ was equal to or greater than $\mathrm{I} \cdot \mathrm{O}$ for each group, including those animals given a supplement of desiccated coconut. The finding of $\mathrm{RQ}$ values greater than unity was in agreement with Mount (I968) for growing pigs.

\section{Effect of a $\beta$-blocking agent on dietary-and cold-induced thermogenesis}

Dietary-induced thermogenesis. Propranolol was used to determine the effect of a $\beta$-blocker on the increased resting metabolic rate associated with a high level of energy intake. Eleven animals given $20 \mathrm{~g}$ feed $/ \mathrm{kg}$ studied at $25^{\circ}$ showed no statistically significant difference in metabolic rate when the measurements were preceded by an injection of either saline or propranolol. However, when the same animals were fed ad lib., propranolol was associated with a statistically significant decrease in $\mathrm{O}_{2}$ consumption of approximately $12 \%(P<0.01)$. The results are given in Fig. 4.

Cold-induced thermogenesis. The effect of propranolol on dietary-induced thermogenesis was compared with its effect on cold-induced thermogenesis by studying five additional pigs on $60 \mathrm{~g}$ feed $/ \mathrm{kg}$. The overnight resting metabolic rate was determined during mild cold exposure of $15^{\circ}$ after the injection of saline or propranolol and also at $25^{\circ}$. Table 4 gives the results and shows that the expected increase in metabolic rate associated with moderate cold exposure was reduced with the $\beta$-blocker by approximately $40 \%$. The rate of $\mathrm{O}_{2}$ consumption at $15^{\circ}$ after propranolol was reduced by $14 \%$ of the control rate.

The $\mathrm{O}_{2}$ consumption of the control animals fed $a d \mathrm{lib}$. or $60 \mathrm{~g}$ feed $/ \mathrm{kg}$ in the propranolol 


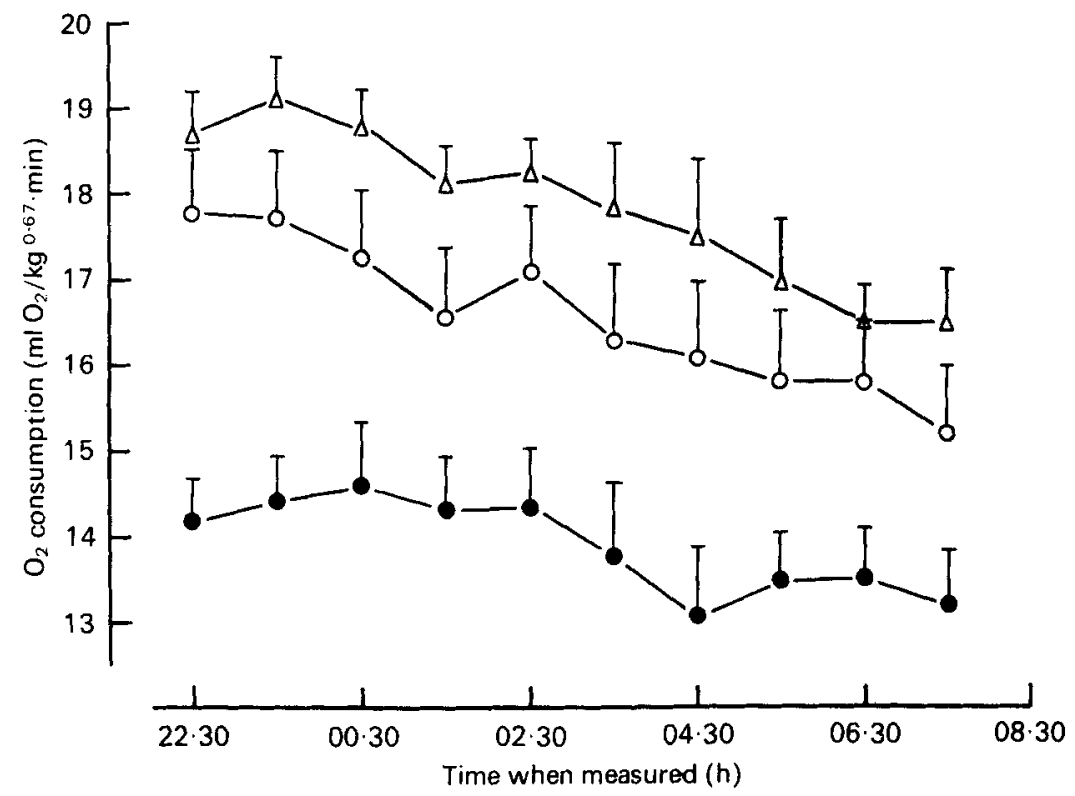

Fig. 2. Rate of oxygen consumption ( $\mathrm{ml} \mathrm{O}_{2} / \mathrm{kg}^{0.67}$ per min) measured overnight in eight pigs after feeding three diets consecutively, each for $7 \mathrm{~d}$. The diets, which were fed at random, were $(\mathrm{g}$ pig feed $/ \mathrm{kg}$ body-weight): $(O) 60 ;(0), 20 ;(\triangle), 20$ plus a quantity of fish meal equivalent in energy content to $40 \mathrm{~g}$ pig feed $/ \mathrm{kg}$ body-weight. Points represent mean values with their standard errors represented by vertical bars. For details of diets, see p. 362 and Tables 1 and 2.

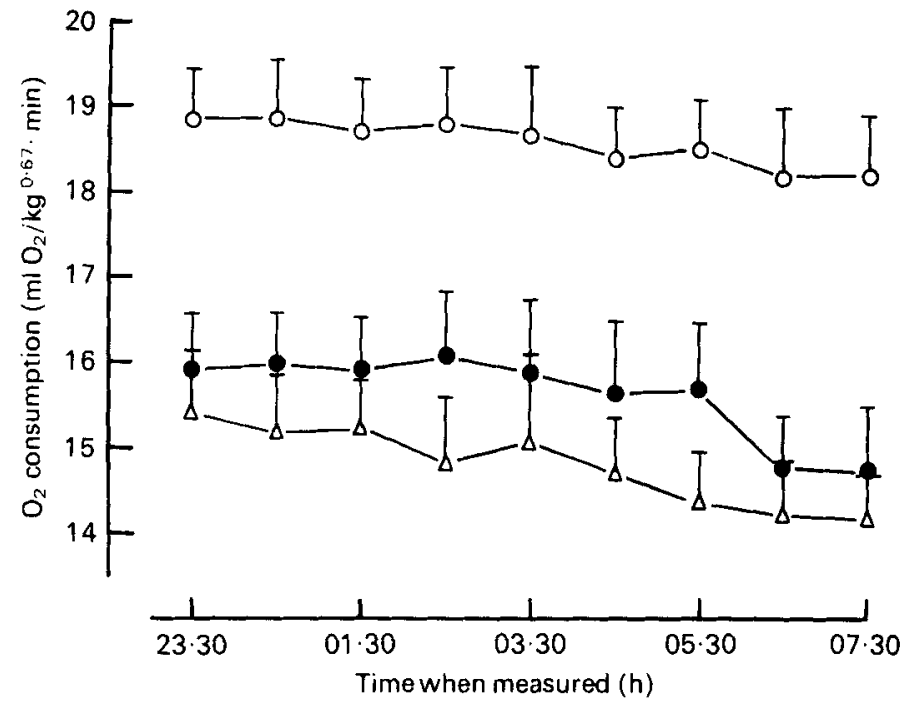

Fig. 3. Rate of oxygen consumption ( $\mathrm{ml} \mathrm{O}_{2} / \mathrm{kg}^{0.67}$ per min) measured overnight in nine pigs after feeding three diets consecutively, each for $7 \mathrm{~d}$. The diets, which were fed at random, were (g pig feed $/ \mathrm{kg}$ body-weight): $(O), 60 ;(O), 20 ;(\Delta), 20$ plus a quantity of glucose equivalent in energy content to $40 \mathrm{~g}$ pig feed $/ \mathrm{kg}$ body-weight. Points represent mean values with their standard errors represented by vertical bars. For details of diets, see p. 362 and Tables 1 and 2. 
Table 3. Respiratory quotients $\left(\mathrm{CO}_{2}\right.$ production : $\mathrm{O}_{2}$ consumption; $\left.\mathrm{RQ}\right)$ for pigs given commercial pig feed at 20 and $60 \mathrm{~g} / \mathrm{kg}$ body-weight and at $20 \mathrm{~g} / \mathrm{kg}$ body-weight with an energy supplement provided by a fat, protein or carbohydrate source

(Mean values with their standard errors)

Regimen

\begin{tabular}{|c|c|c|c|}
\hline \multirow{2}{*}{$\begin{array}{c}\text { Pig feed } \\
\text { (g/kg body-wt) }\end{array}$} & \multirow[b]{2}{*}{ Supplement } & \multicolumn{2}{|c|}{$\mathbf{R Q}$} \\
\hline & & Mean & SE \\
\hline 20 & - & $1 \cdot \infty$ & 0.037 \\
\hline 60 & - & $1 \cdot 22$ & $0.04 I$ \\
\hline 20 & Desiccated coconut & $1 \cdot 28$ & 0.006 \\
\hline 20 & Fish meal & $1 \cdot 04$ & 0.056 \\
\hline 20 & Glucose & $I \cdot 21$ & 0.069 \\
\hline
\end{tabular}

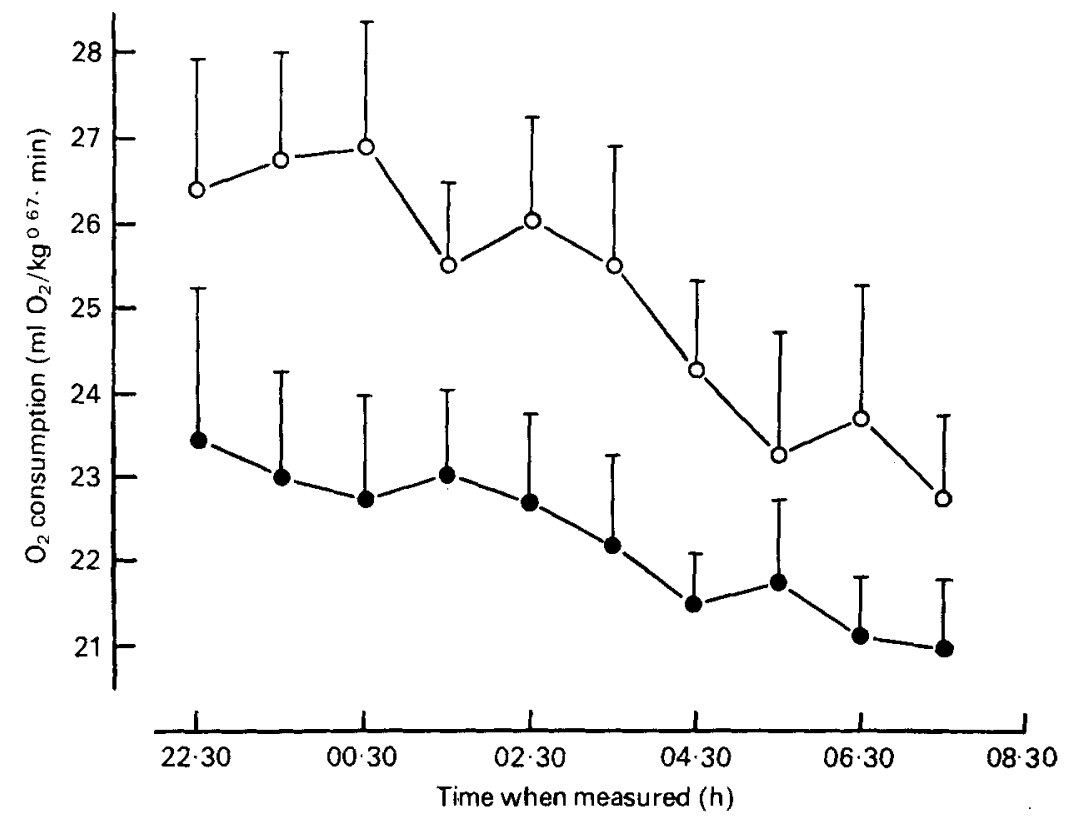

Fig. 4. Rate of oxygen consumption ( $\mathrm{ml} \mathrm{O}_{2} / \mathrm{kg}^{0.67}$ per $\mathrm{min}$ ) measured overnight in eleven pigs. The animals were fed ad lib. (approximately $80 \mathrm{~g} / \mathrm{kg}$ body-weight) on a commercial pig feed. ( $O$ ), After subcutaneous injection of saline $(9 \mathrm{~g}$ sodium chloride/1); (O), after subcutaneous injection of propranolol $(5 \mathrm{mg} / \mathrm{kg})$. Points represent mean values with their standard errors represented by vertical bars. For details of diets, see p. 362 and Tables $I$ and 2.

studies was greater than that of the animals given $60 \mathrm{~g}$ feed $/ \mathrm{kg}$ in the studies on nutrient composition. The reason for this was unknown, although the two series of experiments were carried out at different times.

\section{DISCUSSION}

The present results demonstrate that the increased rate of resting metabolism which is observed in young growing pigs after feeding a high energy intake for $7 \mathrm{~d}$ persists for at least $20 \mathrm{~h}$ after the last meal. This effect is not related merely to the total energy content of the food, but depends on the form in which the energy is presented. Moreover the enhanced rate of resting metabolism associated with a high energy intake can be reduced by the $\beta$-blocker propranolol. Two topics will be considered in relation to these findings: one is whether the mechanisms which give rise to the increase in metabolism immediately after a meal are the 
Table 4. Rate of oxygen consumption $\left(\mathrm{ml} \mathrm{O}_{2} / \mathrm{kg}^{-0.67}\right.$ per min) of five pigs. Measurements were made overnight at $25^{\circ}$ and also at $15^{\circ}$ after injection of saline ( $9 \mathrm{~g}$ sodium chloride/ $\mathrm{I}$ ) or propranolol

(Mean values with their standard errors)

Ambient temperature $\left(^{\circ}\right) \quad \ldots \quad 25$

15

\begin{tabular}{|c|c|c|c|c|c|c|}
\hline \multirow[b]{3}{*}{ Pig } & \multirow[b]{3}{*}{ Mean } & & & & & \\
\hline & & \multirow[b]{2}{*}{ SE } & \multicolumn{2}{|c|}{ Saline } & \multicolumn{2}{|c|}{ Propranolol } \\
\hline & & & Mean & SE & Mean & SE \\
\hline A & $29 \cdot 1$ & 0.32 & $41 \cdot 2$ & 0.59 & $33 \cdot 6$ & 0.43 \\
\hline B & $20 \cdot 7$ & 0.68 & $33 \cdot 6$ & 0.88 & $30 \cdot I$ & 1.02 \\
\hline C & $28 \cdot 4$ & 1.93 & $35 \cdot 2$ & 0.23 & $3 I \cdot 3$ & 0.26 \\
\hline D & $18 \cdot I$ & 0.26 & 33.3 & 0.74 & 26.9 & 0.72 \\
\hline $\mathrm{E}$ & 18.2 & $0.4 \mathrm{I}$ & $28 \cdot 3$ & 0.37 & $26 \cdot I$ & $0 \cdot 38$ \\
\hline
\end{tabular}

same as those which sustain the increase many hours later; the other is the extent to which the processes involved in non-shivering thermogenesis in response to cold resemble those which occur I0-I $2 \mathrm{~h}$ after a meal with a high energy content.

As a result of earlier studies (Lusk, 1930) it was suggested that the immediate increase in metabolic rate after ingestion of a meal depended mainly on its protein content. It was already known, however, that this was not simply due to the energy cost of absorption, since an increase in metabolic rate also occurred after the infusion of amino acids (Benedict \& Emmes, 1912). The idea that it could be related to the production of urea was advanced by Krebs (1964), but the view has been challenged by Garrow \& Hawes (1972) who failed to find a correlation between urea production and the rate of $\mathrm{O}_{2}$ consumption. In any event, an increase in metabolic rate after the ingestion of glucose alone has also been found in man (Pittet et al. 1976). Nevertheless the present study showed that even $20 \mathrm{~h}$ after a meal the highest metabolic rates were recorded after a high intake of protein. It may also be of significance that the diet supplemented with desiccated coconut was low in protein and that the metabolic rate was between the values for 20 and $60 \mathrm{~g} \mathrm{pig} \mathrm{feed} / \mathrm{kg}$ body-weight. The present results do not therefore contradict the idea that the increased metabolic rate was related mainly to the protein content of the food.

The heat production of pigs given desiccated coconut was between the values for 20 and $60 \mathrm{~g}$ pig feed $/ \mathrm{kg}$ body-weight. This may have been due to the thermogenesis associated with medium-chain fatty acids being mainly completed by the time measurements were made, and at least some of the extra heat production could have been related to the breakdown of fibre in the large intestine.

In a study on man involving over-eating, Miller et al. (1967) estimated the rate of $\mathrm{O}_{2}$ consumption from the periodic collection of expired air. They found that at the end of 3 weeks the metabolic rate calculated for a $24 \mathrm{~h}$ period had increased. However this increase was related to the extra $\mathrm{O}_{2}$ used during exercise after a meal, while the basal metabolic rate (BMR) remained unchanged. In another investigation using women, Glick et al. (1977) found that their subjects over-ate for $5 \mathrm{~d}$ without any effect on $\mathrm{O}_{2}$ consumption as estimated from collection of expired air, either during exercise, or at rest. By contrast Apfelbaum et al. (I97I) studied subjects who had over-eaten for $15 \mathrm{~d}$ and were then placed in a chamber while $\mathrm{O}_{2}$ consumption was measured for $24 \mathrm{~h}$. Over-eating was followed by an increase in $\mathrm{O}_{2}$ consumption, and eating a low-energy-high-protein diet was followed by a decrease in $\mathrm{O}_{2}$ consumption over the whole $24 \mathrm{~h}$. Strong et al. (1967) also found that subjects who had been over-eating had higher metabolic rates during the night, although BMR was unchanged. The demonstration of a relation between energy intake and metabolic rate in sheep (Graham et al. 1959) and pigs (Close et al. 1971) has already been mentioned. 
Those studies on man which are at variance with the present results in reporting no effect of energy intake on resting metabolic rate have relied on the sampling of expired air over short periods. It is possible that the use of this technique may disturb the subject sufficiently to obscure any differences in resting metabolic rate. In addition the increased energy intake used by Miller et al. (1967) was approximately $25 \%$ while that used by Glick et al. (1977) approached $50 \%$; both these increases were smaller than that used in the present study.

The effect on resting metabolic rate of feeding extra energy in the form of specific nutrients has received little attention. In man, Goldman et al. (1975) have reported the results of a study on groups of four subjects, some of whom were or had been obese. The same individuals were not consistently represented in each group and only periodic measurements of gaseous exchange were made. After being fed extra fat as corn oil $(3.6 \mathrm{MJ} / \mathrm{d})$ for $83 \mathrm{~d}$ three subjects increased their BMR by 29,13 and $6 \%$ of the control value, and one decreased it by $5 \%$. Over-feeding of 'flavoured corn sugar' $(7.6 \mathrm{MJ} / \mathrm{d})$ for $\mathrm{I} 8 \mathrm{~d}$ was followed by an increase in BMR of $22,15,9$ and $2 \%$. The number of subjects was small but a paired $t$ test on the values for carbohydrate was just statistically significant $(P<0.05)$. More recently, however, Burse et al. (1977) reported that the BMR was unchanged after over-feeding carbohydrate or fat.

There are several possible mechanisms by which dietary-induced thermogenesis might be generated and these have recently been listed by Sims (1976). Similar mechanisms may also be activated during exposure to cold, but few demonstrations of their importance are available. In the bumble bee (Bombus species) a futile cycle involving the inter-conversion of fructose-6-phosphate and fructose-1,6-diphosphate is deployed in the flight muscles before the animal takes off on cold days (Newsholme et al. 1972; Clarke, Bloxham et al. 1973). A similar mechanism has been implicated in the development of malignant hyperthermia in pigs (Clarke, Williams et al. 1973). The sort of non-shivering thermogenesis which has received most attention is that exhibited by rodents, and many newborn mammals. This is associated with the presence of brown fat (Himms-Hagen, I972; Jansky, 1973); but in the pig this tissue is not present even at birth when the body contains less than Io $\mathrm{g}$ total $\mathrm{fat} / \mathrm{kg}$ (McCance \& Widdowson, 1959). In spite of the absence of brown fat, however, the pig does respond to adrenaline and noradrenaline by a small increase in metabolic rate(LeBlanc $\&$ Mount, I968). Moreover during the first $14 \mathrm{~d}$ of post-natal life in pigs the increase in metabolic rate which occurs on exposure to cold is reduced after the administration of the $\beta$-blocker propranolol (Kaciuba-Uscilko \& Ingram, 1976). In sheep it has been shown that after a large dose of propranolol there is a reduction in cold-induced thermogenesis (Webster \& Hays, I968) but as in the present study propranolol had no effect on the metabolic rate during a meal. The present study has shown that propranolol decreased thermogenesis of pigs in the cold and also reduced the increased metabolic rate associated with a high energy intake. The reduction in pigs on a high energy intake does not appear to be simply a result of reduced activity or muscle tension since propranolol had no statistically significant effect on the metabolic rate of pigs fed on a low energy intake. There remains the possibility that the reduction in metabolic rate in the cold after propranolol is related to its effect on dietary-induced thermogenesis since no observations were made on animals given only $20 \mathrm{~g}$ pig feed $/ \mathrm{kg}$ body-weight when exposed to cold.

There are a number of possible explanations for the finding that an energy supplement given as glucose did not increase the rate of metabolism $12-20 \mathrm{~h}$ after the last meal. One is that the processes of breakdown and synthesis continue for up to $20 \mathrm{~h}$ after feeding complex nutrients, but that the glucose can be dealt with over a much shorter period. The results might also be explained by the fact that the amounts of protein and fibre present in the diet supplemented with glucose were the same as those in the $20 \mathrm{~g}$ pig feed $/ \mathrm{kg}$. Any heat production in the large intestine associated with the breakdown of fibre would therefore be the same in 
both diets. Another possible contributory factor to the lower energy expenditure of animals fed on glucose may be the lower energy cost of using glucose or glycogen as fuel, since gluconeogenesis is avoided (Blaxter, 1971). Finally it may be that the dietary-induced thermogenesis associated with simple food substances is not additive. Thus Pittet et al. (1974) found that heat production after feeding amino acids was increased by $17 \%$ and after glucose by $14 \%$; but when both amino acids and glucose were given the increase was still only $17 \%$. Moreover Elwyn et al. (1978) found that patients recovering from surgery tended to have lower metabolic rates when glucose was added to infusions of amino acids. The speculative suggestion is that glucose tends to reduce dietary-induced thermogenesis possibly by increasing insulin levels and exerting a nitrogen-sparing effect.

The authors thank Mr D. E. Walters, ARC Statistics Group, Cambridge, for his help, and $\mathrm{Mr} \mathrm{K}$. F. Legge for his technical assistance.

\section{REFERENCES}

Apfelbaum, M., Bostsarron, J. \& Lacatis, D. (1971). Am. J. clin. Nutr. 24, 1405.

Benedict, F. G. \& Emmes, L. E. (I9I2). Am. J. Physiol. 30, 197.

Blaxter, K. L. (1971). Fedn Proc. Fedn Am. Soss. exp. Biol. 30, 1436.

Burse, R. L., Goldman, R. F., Danforth, E., Horton, E. S. \& Sims, E. A. H. (1977). Fedn Proc. Fedn Am. Socs. exp. Biol. 36, 546 Abstr. 1456.

Cairnie, A. B. \& Pullar, J. D. (I959). Br. J. Nutr, r3, 43 I.

Clarke, M. G., Bloxham, D. P., Holland, P. C. \& Lardy, H. A. (1973). Biochem. J. 134, 589.

Clarke, M. G., Williams, C. H., Pfeifer, W. F., Bloxham, D. P., Holland, P. C., Taylor, C. A. \& Lardy, H. A. (1973). Nature, Lond. 245, 99.

Close, W. H., Mount, L. E. \& Start, I. (1971). Anim. Prod. r3, 285.

Elwyn, D. H., Gump, F. E., lles, M., Long, C. L. \& Kinney, J. M. (1978). Metabolism $27,325$.

Evans, S. E. \& Ingram, D. L. (1977). J. Physiol, Lond. 264, 51 I.

Garrow, J. S. \& Hawes, S. F. (1972). J. Nutr. 27, 21 I.

Glick, Z., Shvartz, E., Magazanik, A. \& Modan, M. (1977). Am. J. clin. Nutr. 3o, 1026.

Goldman, R. F., Haisman, M. F., Bynum, G., Horton, E. S. \& Sims, E. A. H. (1975). In Obesity in Perspective, p. I65 [G. A. Bray, editor]. Washington DC: U.S. Government Printing Office.

Graham, N. McC., Wainman, F. W., Blaxter, K. L. \& Armstrong, D. G. (1959). J. agric. Sci., Camb. 52, 13.

Himms-Hagen, J. (I972). In Handbook of Experimental Pharmacology, vol. 33, p. 363 [H. Blaschko and E. Muscholl, editors]. Berlin: Springer Verlag.

Hodgman, C. D. (1962). Editor of Handbook of Chemistry and Physics. Cleveland, Ohio: The Chemical Rubber Publishing Co.

Ingram, D. L. \& Kaciuba-Uscilko, H. (1977). J. Physiol, Lond. 270, 43I.

Jansky, L. (1973). Biol. Rev. 48, 85.

Kaciuba-Uscilko, H. \& Ingram, D. L. (1976). Comp. Biochem. Physiol. 56C, 53.

Krebs, H. A. (1964). In Mammalian Protein Metabolism, vol. I, p. 125 [H. N. Munro and J. B. Allison, editors]. New York: Academic Press.

LeBlanc, J. \& Mount, L. E. (1968). Nature, Lond. $217,77$.

Lusk, G. (1928). The Science of Nutrition, 4th ed, p. 276. Philadelphia and London: Saunders.

Lusk, G. (1930). J. Nutr. 3, 519.

McCance, R. A. \& Widdowson, E. M. (1959). J. Physiol., Lond. 147, 124.

Miller, D. S., Mumford, P. \& Stock, M. J. (1967). Am. J. clin. Nutr. I1, I 223.

Mount, L. E. (1968). In The Climatic Physiology of the Pig, p. 103. London: Edward Arnold.

Newsholme, E. A., Crabtree, B., Higgins, S. J., Thornton, S. D. \& Start, C. (1972). Biochem. J. I28, 89.

Paul, A. A. \& Southgate, D. A. T. (1978). McCance \& Widdowson's The Composition of Foods, 4 th ed. London: HMSO.

Pittet, P., Chappuis, P., Acheson, K., de Techtermann, F. \& Jéquier, E. (1976). Br. J. Nutr. 35, 28 I.

Pittet, P., Gygax, P. H. \& Jéquier, E. (1974). Br. J. Nutr. 31, 343.

Rowell, J. G. \& Walters, D. E. (I976). J. agric. Sci., Camb. 87, 423.

Rubner, M. (1902). Die Gesetze des Energieverbrauchs bei der Ernährung, p. 333. Leipzig: Deutiche.

Sims, E. A. H. (1976). Clin. Endocr. Metab. 5, 377.

Strong, J. A., Shirling, D. \& Passmore, R. (1967). Br. J. Nutr. 2r, 909.

Webster, A. J. F. \& Hays, F. L. (1968). Can. J. Physiol. Pharmacol. 46, 577. 